\title{
Equivalent Circuit Model of Semiconducting Single Walled Carbon Nano Tube based Bulk Hetero Junction Organic Solar Cell in Comparison with Experimental Results
}

\author{
P. Swapna \\ Assistant Professor \\ Dept. of Instrument Technology, \\ A.U College of Engineering (A), Andhra University, \\ Visakhapatnam, AP
}

\author{
Y. Srinivasa Rao \\ Professor, \\ Dept. of Instrument Technology \\ A.U College of Engineering (A), \\ Andhra University, Visakhapatnam, AP
}

\begin{abstract}
In this paper, the characteristics of organic bulk heterojunction solar cells have been designed and modeled using MATLAB R2010a version. Here, organic solar cell is considered as a diode and an equivalent circuit is developed with series and shunt resistances to obtain the I-V characteristics of the model. Non-linear equations are obtained in by solving the equivalent circuit model. These non-linear equations are solved using Newton-Raphson method. The theoretical results thus obtained are compared with practical results and an observation made is that are theoretical results are close to the results obtained from fabricated structure.
\end{abstract}

\section{Keywords}

Short circuit current $\left(\mathrm{I}_{\mathrm{sc}}\right)$, Open circuit Voltage $\left(\mathrm{V}_{\mathrm{oc}}\right)$, Efficiency, Fill Factor, Single diode solar cell, equivalent circuit model.

\section{INTRODUCTION}

The worldwide consumption of energy has increased every year by several percentages over the last thirty years [1]. Nowadays, most of energy is supplied by fossil fuels which release green house gases into the atmosphere. Hence we use renewable energy resource which is pollutant free. Solar energy is one of the readily available renewable energy resources and pollutant free. Photovoltaic is a method of generating electrical power by converting solar radiation that exhibit the photovoltaic effect. The most recent and efficient polymer solar cells fabricated today are based on the concept of bulk heterojunction [J.L. Segura]. An accurate knowledge of solar cell parameters from experimental data is of vital importance for the design of solar cells and for the estimates of their performance. Thus, different solar cell models have been developing to describe their electrical behavior, but the electrical equivalent circuit is a convenient and most common way in simulation studies. The five parameters of interest in the equivalent circuit are the photo-current $\left(\mathrm{I}_{\mathrm{PV}}\right)$, series resistance $\left(R_{\mathrm{s}}\right)$, diode saturation current $\left(\mathrm{I}_{0}\right)$, parallel resistance $\left(\mathrm{R}_{\mathrm{sh}}\right)$ and the ideality factor $(\mathrm{n})$. The current-voltage relationship of a solar cell is described by a mathematical equation that is both implicit and nonlinear. Here, NewtonRaphson method is used to solve the implicit nonlinear equation of I-V relation [1-3].

Daniel S.H Chan et al, described an analytical solution for the rapid extraction of single and double diode-model parameters; experimental data was accurate for Rs less than $200 \mathrm{~m} \Omega$ at $\mathrm{I}_{\mathrm{ph}}=1 \mathrm{~A}[4,5,6]$. J.A Barker et al, developed a numerical model to predict the current-voltage curves of bilayer conjugated polymer photovoltaic devices [7]. B.Mazhari examined a conventional circuit model for interpreting results obtained using organic solar cells $[8,9]$. L.J.A.Koster et al, developed a numerical device model that consistently describes the current-voltage characteristics of polymer:fullerene bulk heterojunction solar cells $[10,11]$. A.Cheknane et al , modeled a bulk heterojunction solar cell by introducing interfacial layer in between ITO electrode and active layer as PEDOT/PSS and by varying the thickness of active layer [9].The electric circuit model was done based on one diode and two diode model as suggested by Nunzi et al [12]. The Newton's method was chosen to solve the models. To evaluate accuracy of the models, output characteristics of the solar panel provided from simulation results were compared with the data obtained from experimental results [13-18].

Safae Aazou et al, presented a full comparative study of two different bulk heterojunction organic solar cells. After the device fabrication, the solar cells are characterized under dark and illumination conditions [19]. An electronic circuit model as suggested by A.Ortzi-Conde et al, is adopted to model the fabricated solar cells and extract the parameters by using different methods [20].

Section 1 describes the introduction and literature survey of equivalent circuit model for single and double diode models. Section 2 deals with the single diode model and parameter extraction from I-V curve. Section 3 deals solving of nonlinear current equation using Newton - Raphson methods and $\mathrm{I}-\mathrm{V}$ characteristics obtained for single diode model. Lastly, comparison of the simulation results with experimental results along with the conclusion is presented.

\section{SINGLE DIODE MODEL}

The characteristics of a solar cell "current versus voltage" under environmental Conditions was usually translated to an equivalent circuit of single diode as shown in

Figure 1 containing photocurrent source Iph, a diode, a shunt resistance (Rsh) and a series resistance (Rs) in the load branch.

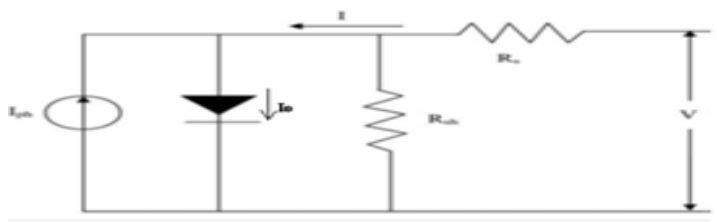

Figure 1: Single diode model 
One diode model can be represented by Equation.(1)

$$
\begin{gathered}
I=I_{p h}-I_{01}\left\{\exp \left(\frac{V+I R_{S}}{V_{T}}\right)-1\right\}-\frac{V+I R_{S}}{R_{S h}}, \\
V_{T}=\frac{n k T}{q}
\end{gathered}
$$

Where,

$\mathrm{I}_{01}$ is the saturation current under reverse bias

$\mathrm{q}$ is the electronic charge,

$\mathrm{k}$ is Boltzmann's constant

$\mathrm{T}$ is the temperature in Kelvin

According to Mazhari model [5], central assumption in the conventional model is that photo-generated current $\mathrm{I}_{\mathrm{Ph}}$ is constant for given incident light intensity and is independent of voltage. A more general model for organic solar cell is one where photo-generated current $\mathrm{I}_{\mathrm{ph}}$ is also a function of voltage. In order to demonstrate the validity of this assertion, consider the open-circuit condition described by Eq. (3) which relates that photocurrent is dependent on open circuit voltage. And its value at open-circuit condition is negligible compared to short-circuit condition. In this extreme case, the opencircuit condition occurs more due the photo-generated current decreasing to zero by itself.

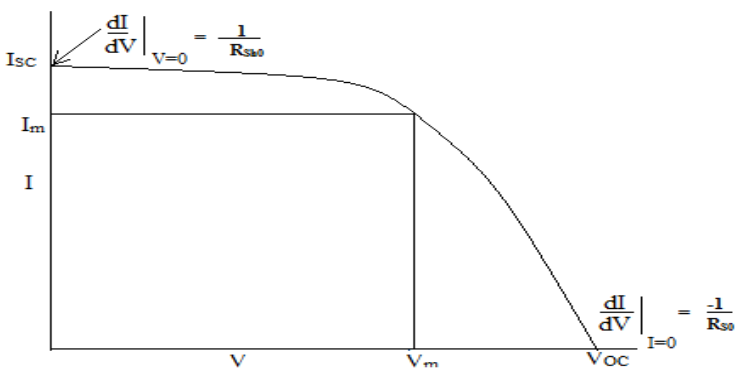

Figure 2: I-V characteristics curve

At the short circuit point, $\mathrm{V}=0, \mathrm{I}=I_{s c}$ gives

$I_{s c}=I_{p h}-I_{01}\left(\exp \frac{I_{s c} R_{S}}{V_{T}}-1\right)-\frac{I_{s c} R_{S}}{R_{s h}}$

At open circuit point, $\mathrm{V}=\mathrm{Voc}, \mathrm{I}=0$ gives

$$
I_{p h}=I_{01}\left(\exp \frac{V_{o c}}{V_{T}}-1\right)+\frac{V_{o c}}{R_{s h}}
$$

In an organic solar cell, the series resistance depends on the resistivities of the active material(s), the graphene electrode and the its interface. Under illumination, $I_{p h}$ is equal to number of dissociated excitons/s, i.e., number of free electron/hole pairs per second, immediately after generation, before any recombination takes place [21]. The shunt resistor $\mathrm{R}_{\mathrm{sh}}$ is due to recombination of charge carriers near the dissociation site (e.g. donor/acceptor interface) and it may also include recombination farther away from the dissociation site (e.g. near electrode). The series resistance $R_{s}$ reflects conductivity, i.e. mobility of specific charge carrier in the respective medium.

In singe-diode model [2], there will be five unknown parameters; $\mathrm{I}_{p h}, I_{01}, n, R_{s}$ and $R_{s h}$. Analytical expressions for the extraction of the model parameters are described in J.C.H.Phang et al [3]. The unknown parameters can be calculated by using the following equations such as,

$$
\begin{gathered}
n=\frac{V_{m}+I_{m} R_{s 0}-V_{o c}}{V_{T}\left\{\ln \left(I_{s c}-\frac{V_{m}}{R_{s h}}-I_{m}\right)-\ln \left(I_{s c}-\frac{V_{o c}}{R_{s h}}\right)+\frac{I_{m}}{I_{s c}-V_{o c} / R_{s h} 0}\right\}} \\
\mathrm{I}_{01}=\left(\mathrm{I}_{\mathrm{sc}}-\frac{\mathrm{V}_{\mathrm{oc}}}{\mathrm{R}_{\mathrm{sh}}}\right) \exp \left(\frac{-\mathrm{V}_{\mathrm{oc}}}{\mathrm{nV}}\right) \\
R_{\mathrm{T}}=R_{s 0}-\frac{n V_{T}}{I_{s c}} \exp \left(\frac{-V_{o c}}{n V_{T}}\right) \\
R_{s h}=R_{s h 0} \\
I_{p h}=I_{s c}\left(1+\frac{R_{s}}{R_{s h}}\right)+I_{0}\left(\exp \frac{I_{s c} R_{s}}{n V_{T}}-1\right)
\end{gathered}
$$

Where $V_{o c}, I_{s c}, V_{m}, I_{m}, R_{s 0}$ and $R_{s h 0}$ are the input parameters defined from the experimental data.

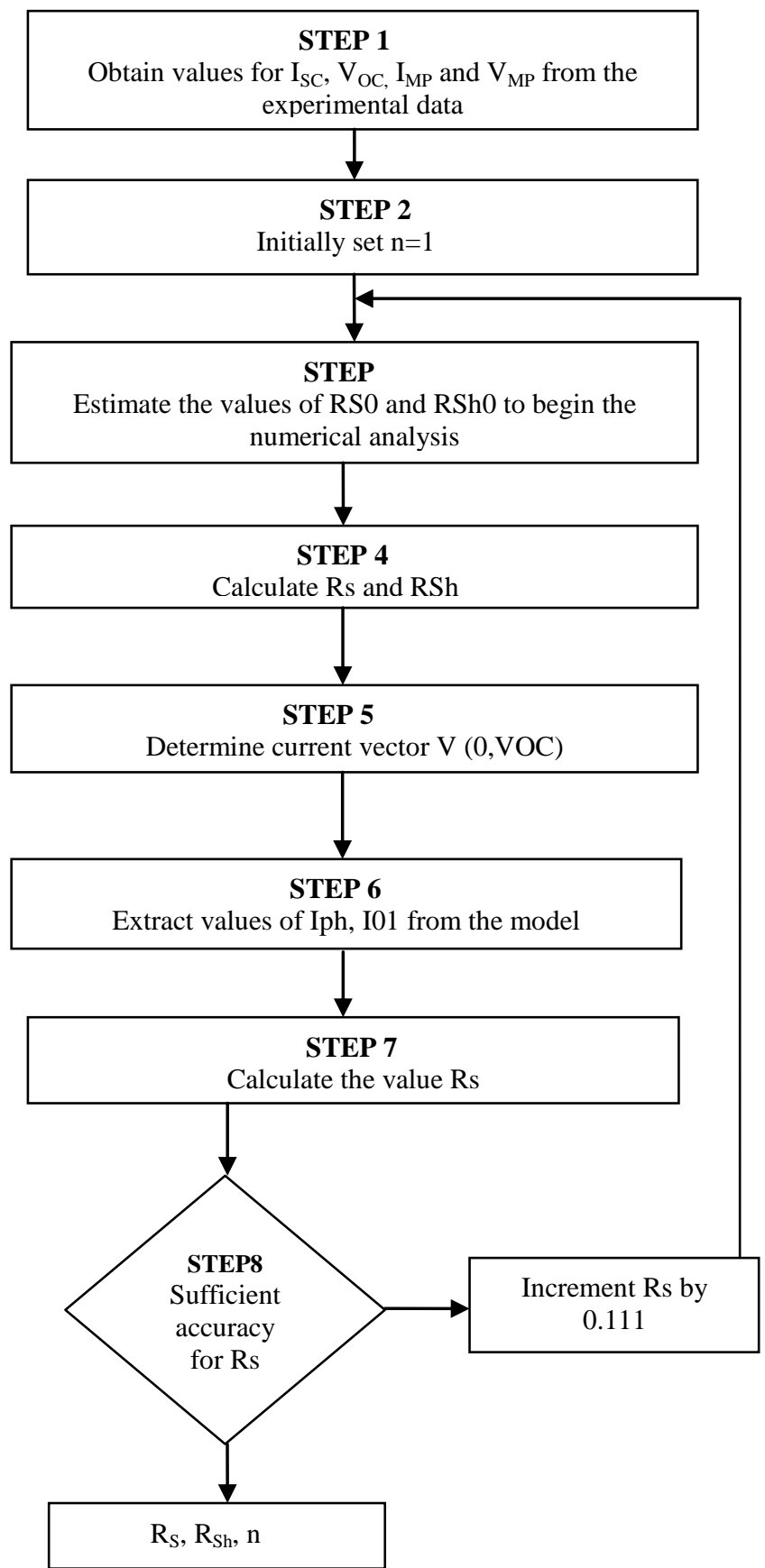

Figure 3: Overview of the algorithm used to extract circuit parameters from the experimental data 


\section{SIMULATION RESULTS}

Based on the experimental results, initial values of sheet resistance $\left(\mathrm{R}_{\mathrm{sh}}\right)$ and shunt resistance values are obtained as shown in Figure 2. Initially consider the ideality factor to be 1 and evaluate all the equations from 1 to 8 ; the value of photogenerated current $\left(\mathrm{I}_{\mathrm{ph}}\right)$, diode current $\left(\mathrm{I}_{01}\right)$ are obtained and tabulated in Table 1. The process flow of extraction of model parameters is shown in Figure 3. Before processing further, currents (I) obtained from Equation 6.1 are converted into current density $(\mathrm{J})$ by multiplying the active cell area. Equation 6.1 becomes non-linear for different values of V. So, Newton-Raphson method is used to solve the non-linear equation in MATLAB 2010 (a) version. Simulated J-V plots based on each model are constructed and the simulated plots are compared to the experimental results obtained earlier [5]. Figure 6.4 to 6.6 show simulated $\mathrm{J}-\mathrm{V}$ plots for $\mathrm{BHJ}$ structure OSC based on the single-diode model. Figure 6.4 shows that the calculated values based on single diode model are close to the experimental values.

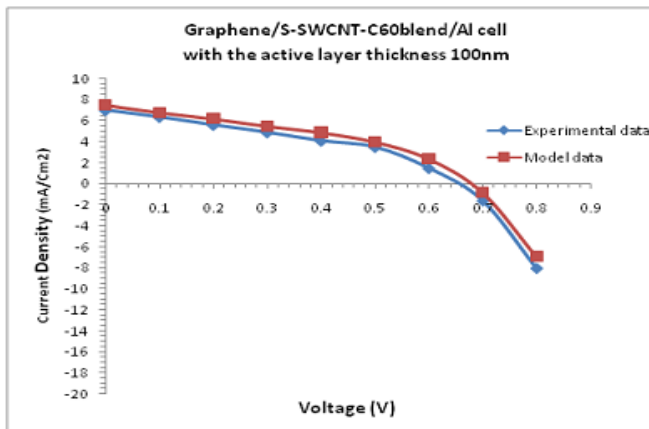

Figure 4: J-V plot for single diode model and experimental data with 100nm thick active layer

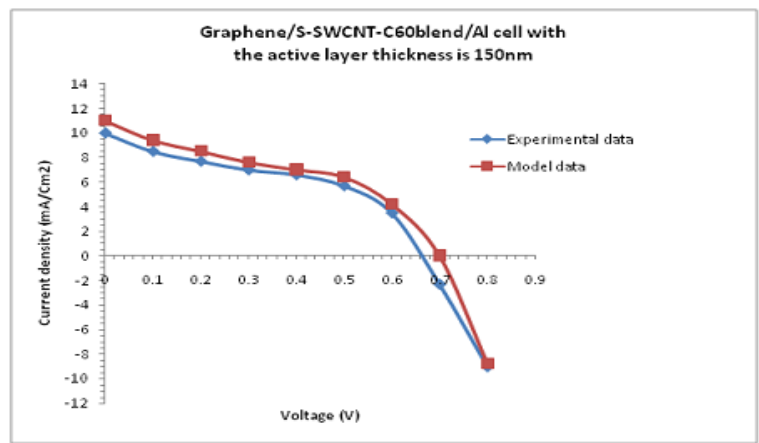

Figure 5: J-V plot for single diode model and experimental data with $150 \mathrm{~nm}$ thick active layer

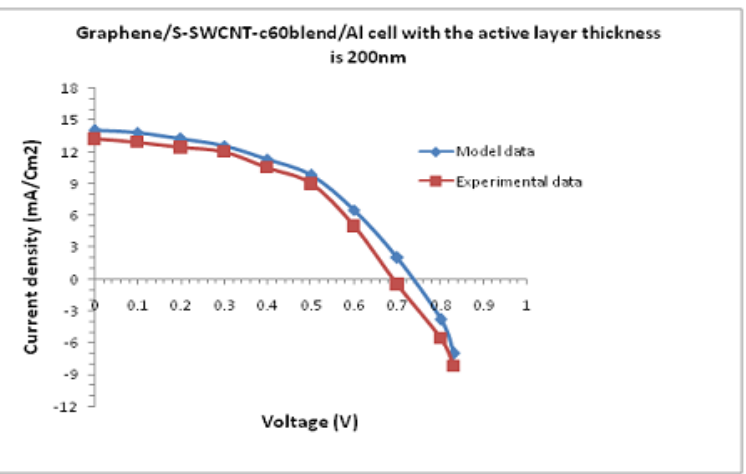

Figure 6: J-V plot for single diode model and experimental data with $200 \mathrm{~nm}$ thick active layer

\section{CONCLUSION}

A single diode model has been applied here to describe a Graphene/S-SWCNT-C60 blend/Al based BHJ structure organic solar cell characteristics. Based on the experimental J$\mathrm{V}$ curves, the circuit parameters like shunt resistance $\left(\mathrm{R}_{\mathrm{sh}}\right)$, series resistance $\left(\mathrm{R}_{\mathrm{s}}\right)$ and ideality factor $(\mathrm{n})$ are extracted using Newton Raphson method in Matlab. The model values have been compared with experimental results extracted using Newton - Raphson method in Matlab. The model values have been compared with the experimental results. It concludes that the model values resemble experimental values with considerable variation. This variation may be resolved by using two diode model.

\section{REFERENCES}

[1] B.BA and M.KANEl Determination of polysilicon solar cell parameters using electrical short-circuit current Decay methodll Solid-State Electronics,vol.42,N0.4,pp.541-545, 1998

[2] L.Sandrolini, M.Artioli,U.ReggianillNumerical method for the extraction of photovoltaic module double- diode model parameters through cluster analysis Applied Energy 87 (2010),442-451

[3] Kashif Ishaque, Zainal Salam, Saad Mkhilef, Amir Shamsudin\|Parameter extraction of solar photovoltaic modules using penalty - based differential evolutionll Applied Energy 99 (2012),297-308

[4] Daniel S.H Chan, Member, EEE, and Jacob C.H Phang, Member, EEE(1987) "Analytical Methods for the Extraction of Solar-Cell Single and Double-Diode Model Parameters from I-V Characteristics"IEEE Transactions on Electron Devices, vol.ED-34,no. 2.

[5] J.C.H Phang, D.S.H.Chan and J.R.Phillips (1984) "Accurate analytical method for extraction of solar cell model parameters ," Electron. Lett. , vol.20 , no.10, pp.406-408.

[6] Tony K.P.Wong and Philip C.H.Chan, (1994) "An equivalent circuit approach to solar cell modeling" ,proceedings of IEEE HKEDM ,cat \#:IEEE-94 ${ }^{\mathrm{TH}} 0704-7$.

[7] J.A.Barker, C.M.Ramsdale, N.C.Greenham(2003), Phys.Rev. B $67,75205$.

[8] B.Mazhari (2006)“An improved Solar Cell circuit model for organic solar cells" Solar Energy Materials \& Solar Cells 90, 1021-1033.

[9] L.J.A.Koster, EC.P.Smits, V.D. Mihailetchi and P.W.M.Blom (2005) "Device model for the operation of polymer/fullerene bulk heterojunction solar cell" Physical Review B 72, 085205.

[10] H.K. Gummel (1964) IEEE Trance. Electron Devices 11,455 .

[11] A.Cheknane, T.Aernouts et M.Merad Boudia(2007) "Modeling and Simulation of Organic Bulk Heterojunction solar cells" Revue des Energies Renouvelabls ICRESD-07 Tlemcen 83-90.

[12] J.M.Nunzi (2002)“Organic Materials and Devices for Photovoltaic Applications", ERT Cellules Solaires Photovoltaiques plastiques, Labo POMA, Angers, France,pp.197-224 .

[13] Moshen Taherbanch, Gholamreza Farahani and Karim Rahmani "Evaluation the accuracy of One-Diode and 
Two-Diode models for a solar panel based Open-Air Climate Measurements" cells ", Elsevier, Applied Energy, Vol.32, No.9(December 2006), pp.1724-1730, dio:10.1016/j.energy.2006.12.006.

[14] Castaner, L.; Silvester, S. (2002). “ Modeling photovoltaic systems using pspice" John Wiley \& Sons,ISBN:0-470-84527-9, England.

[15] Sera, D.; Teodorescu, R. \& Rodriguez, P.(2007) "PV panel model based on data sheet values" IEEE International Symposium on Industrial Electronics, ISBN:978-1-4244-0754-5, Spain .

[16] De Soto, W.;Klein, S.A.\& Beckman, W.A.(2006). Improvement and Validation of a model for photovoltaic array performance, Elsevier, Solar Energy, Vol. 80, No.1, (June 2005), pp.78-78, doi:10.1016/j.solener.2005.06.010.

[17] Chenni, R.; Makhlouf, M.; Kerbache,T.\&Bouzid, A.(2007) " A detailed modeling method for photovoltaic
[18] Chunfu Zhang, Jincheng Zhang, Yue Hao, Zhenhua Lin and Chunxiang Zhu (2011) "A simple and efficient solar cell parameter extraction method from a single currentvoltage curve", J. Applied physics, 110, 064504 .

[19] S.Aazou ,A.Ibral, M.S.White, Martin Kal Tenburner E.D.Glowacki, D.A.Egbe, N.S.Sariciftci and E.M.Assid(2013) "Orgnic Bulk Heterojunction Solar Cells Based on P3HT and Anthracene-Containing PPEPPV: Fabrication, Characterization and modeling" Journal of optoelectronics and Advanced Materials vol.13,no.5-6, p.395-404.

[20] A.Ortiz-Conde, F.J.Garcia Sanchez, J.Muci, (2004)“ Solar Energy Materials and Solar cells" 90, p.352.

[21] A. Jain, A. Kapoor, "A new approach to study organic solar cell using Lambert W-function", Sol. Energy Mater. Sol. Cells 86 (2005) 197-205 